Professor of Government, Emeritus, Williams College.

Earl O. Kline, Distinguished Professor, political science, College of Charleston.

Roy Pierce retired from the University of Michigan in June 1993.

Mostafa Rejai, Miami University's first Distinguished Professor, has become the institution's first Distinguished Professor Emeritus in order to devote full time to his research agenda.

Kurt P. Tauber, Class of 1924 Professor of Political Science, Emeritus, Williams College.

\section{Visiting and \\ Temporary Appointments}

Joe Adams, visiting assistant professor, department of political science, Auburn University.

D. Scott Bennett, visiting lecturer, State University of New York at Buffalo.

Michael J. Clancy, visiting assistant professor of political science for the 1993-94 academic year, Williams College.

Raymond Cohen, associate professor of international relations at Jerusalem's Hebrew University, will be the Aaron and Cecile Goldman Visiting Israeli Professor at Georgetown University for 1993-94.

Malcolm L. Goggin, associate professor of political science, University of Houston, is a visiting professor at the University of Strathclyde, Scotland, during the 1993-94 academic year.

David Judge, reader in political science, University of Strathclyde, Scotland, is a visiting professor at the University of Houston during the 1993-94 academic year.

Rene McEldowney, visiting assistant professor, department of political science, Auburn University.

Sophia Mihic, visiting assistant professor of political science for the 1993-94 academic year, Williams College.

David A. Smith, visiting assistant professor, department of political sci- ence, West Virginia University; formerly University of WisconsinMadison.

\section{Awards}

\section{American Academy of Arts and Sciences Fellows and Foreign Honorary Members}

The American Academy of Arts and Sciences announced the election of 195 new Fellows, in recognition of their distinguished contributions to science, scholarship, public affairs, and the arts. Fellows elected from the field of political science are:

Charles V. Hamilton, Columbia University, New York, NY.

Donald L. Horowitz, Duke University, Durham, NC.

Stanley Kelley, Jr., Princeton University, Princeton, NJ.

Donald R. Kinder, University of Michigan, Ann Arbor, MI.

Thomas E. Mann, The Brookings Institution, Washington, DC.

Frank J. Sorauf, University of Minnesota, Minneapolis, MN.

Edward R. Tufte, Yale University, New Haven, CT.

Anthony King, University of Essex, Essex, England, was elected a Foreign Honorary Member in political science.

\section{Woodrow Wilson Center Fellows for 1993-94}

The Woodrow Wilson International Center for Scholars has announced the appointment of 32 Fellows for the academic year 1993-94. Chosen from 802 applicants from 66 countries, they will come to the Center from nine states and the District of Columbia and ten nations other than the United States.

Sumit K. Ganguly, professor of political science, Hunter College of The City University of New York. "The Kashmir Problem Revisited."

Paul A. Rahe, associate professor of history, University of Tulsa. "An Archaeology of Modern Virtue."

Joseph Rothschild, Class of 1919 Professor of Political Science,
Columbia University. "Political Trends, Processes, and Institutions in Post-Communist East Central Europe."

Patricia M. Springborg, reader in government, University of Sydney, Australia. "Solvents of Primordialism: Ethnicity, Nationalism, Racism and Ethics."

\section{The Pew Faculty Fellowship in International Affairs, 1993-94}

Political science faculty who have been awarded Fellowships:

Kurt Taylor Gaubatz, assistant professor, department of political science, Stanford University.

Emily 0. Goldman, assistant professor, department of political science, University of California, Davis.

Lev S. Gonick, assistant professor, department of political science, Wilfrid Laurier University.

Joe D. Hagan, associate professor, department of political science, West Virginia University.

Leah Haus, assistant professor, department of politics, New York University.

Jeanne A. K. Hey, assistant professor, department of political science, Miami University.

Raymond F. Hopkins, professor, department of political science, Swarthmore College.

Daniel R. Kempton, associate professor, department of political science, Northern Illinois University.

Beth Simmons, assistant professor, department of political science, Duke University.

Paul C. Sondrol, assistant professor, department of political science, University of Colorado at Colorado Springs.

\section{Guggenheim Fellowships}

The John Simon Guggenheim Memorial Foundation has awarded fellowships worth a total of $\$ 3.9$ million to 146 artists, scholars, and scientists. The fellows were chosen 
from among 2,989 applicants "on the basis of unusually distinguished achievement in the past and exceptional promise for future accomplishment."

The following political scientists were named Guggenheim Fellows:

Susan Buck-Morss, professor of political philosophy and social theory, Cornell University: modern mass-cultural forms in the U.S. and U.S.S.R.

Wendy Kaminer, public policy fellow, Radcliffe College: capital punishment, politics, and culture.

Wyatt MacGaffey, professor of social sciences, Haverford College: Kongo conceptions of power.

Roger Morris, writer, Santa Fe, NM, and adjunct professor of political science, University of New Mexico: the second volume of a biography of Richard Nixon.

Carole Pateman, professor of political science, University of California at Los Angeles: women and democratic citizenship.

George Tsebelis, associate professor of political science, University of California at Los Angeles, and national fellow at Hoover Institution on War, Revolution, and Peace: the institutions of the European community.

Mary C. Waters, associate professor of the social sciences, Harvard University: the social and economic assimilation of West Indian immigrants in New York City.

\section{Gerald R. Ford Library Grants}

The following political scientists received Ford Library Grants for 1992-93:

John B. Bader, Brookings Institution, "Congressional Leaders, Agendas, and Divided Government."

Larry Berman, University of California-Davis, "Disengaging from Vietnam."

Kenneth E. Collier, University of Kansas, "Executive Branch Relations with Congress."

Clark Hubbard, SUNY Stony Brook,
"The Mass Media Election Revisited: The 1976 Campaign."'

Anthony Kandel, Landers University, "Environmental Policymaking in the Ford Administration."

George Krause, West Virginia University, "The Political Economy of Monetary Policy Decisionmaking."

Brigitta Loesche-Scheller, University of Zurich, "The Legacy of the War on Poverty on U.S. Policymaking."

Timothy J. McKeown, University of North Carolina at Chapel Hill, "The High Politics of U.S. Foreign Aid."'

Michal Skapa, Charles University (Prague), "Curriculum Development Materials on U.S.-East European Materials.",

\section{Hoover Institution Announces National Fellows for 1993-94 Academic Year}

The Hoover Institution has announced the recipients of the annual post-doctoral National Fellowships for the 1993-94 academic year.

Political scientists who have been named 1993-94 Fellows, their topics, and academic background are:

Steven D. Ansolabehere, "The Effects of Television Advertising in Political Campaigns"'; assistant professor, department of political science, University of California at Los Angeles; Ph.D., political science, Harvard University.

Geoffrey M. Garrett, "The Political Economy of Institution-Building in the 'New' European Community"; assistant professor, department of political science, Stanford University; Ph.D., political science, Duke University.

Barbara J. Geddes, "The Initiation of New Democratic Institutions"; associate professor, department of political science, University of California at Los Angeles; Ph.D., political science, University of California at Berkeley.

Kevin J. Middlebrook, "Political Cleavages, Conservative Parties, and Democratization in Latin America"; senior research fellow, Center for
U.S.-Mexican Studies, University of California at San Diego; Ph.D., government, Harvard University.

\section{American Council on Education Fellows}

The American Council on Education sponsors a fellowship program which enables its participants to become involved in academic administration at their own institutions or on other campuses.

The following is a list of political scientists who have been named fellows for 1993-94.

Richard B. Finnegan, Stonehill College.

Mary L. Smith, professor of political science, College of St. Francis (IL).

\section{Lucius Barker Honored by the University of Wisconsin- Milwaukee}

On December 20, 1992 the University of Wisconsin-Milwaukee bestowed on Lucius J. Barker an honorary Doctor of Laws degree. Barker, a scholar of constitutional law, was a member of the Wisconsin-Milwaukee faculty from 1956 to 1967.

The degree was presented by Chancellor John H. Schroeder who read the following citation:

The University of Wisconsin-Milwaukee cites Lucius Jefferson Barker for his outstanding research in public law, American politics, and minority politics, for his excellent teaching at the University of Wisconsin-Milwaukee, Washington University, and Stanford University, for his active support of young scholars, for his service to the profession of political science as the founding editor of The National Journal of Political Science and as current President of the American Political Science Association.

Professor Barker is currently the William Bennett Munro Professor of Political Science at Stanford University. In his career, he has also taught at Indiana University, the University of Illinois, Harvard University, Washington University, and his alma mater, Southern University. 


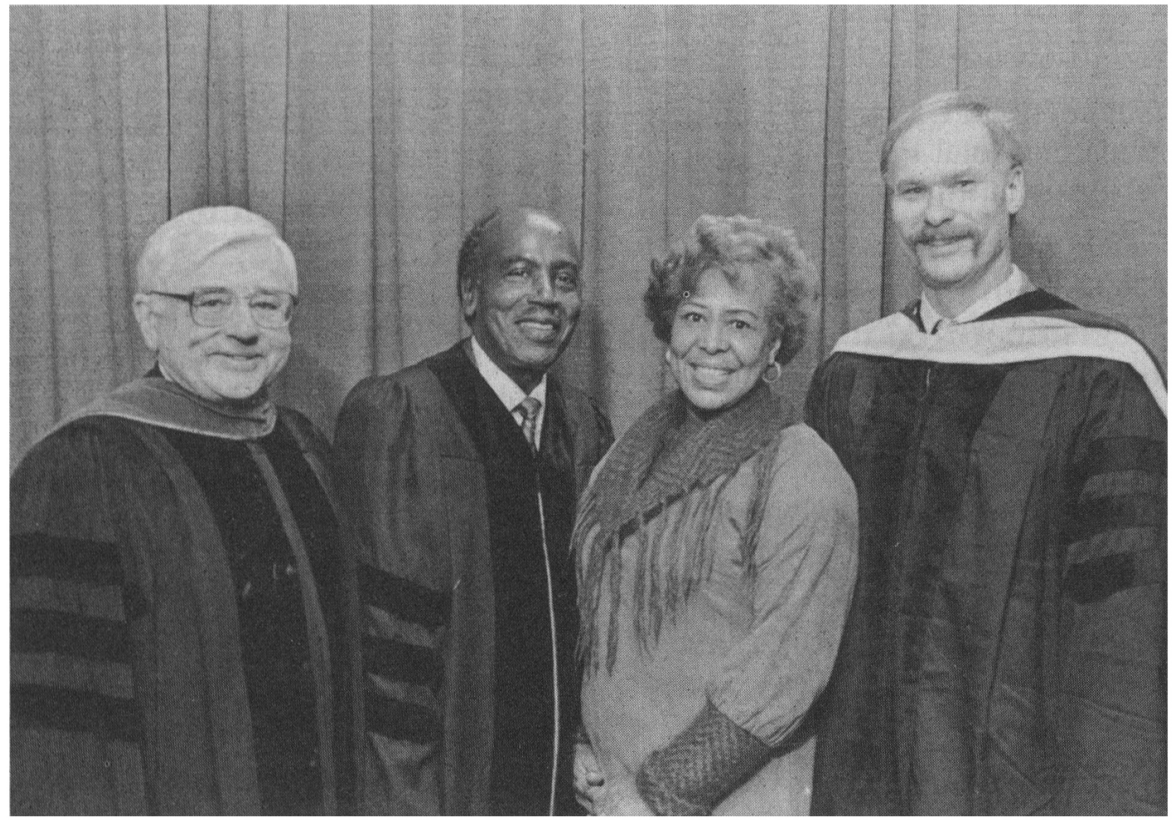

(From left to right) Dean William Halloran, Lucius Barker, Maude Barker, Kenneth Meier.

\section{Other Awards and Honors}

Weston Agor, department of political science, University of Texas at El Paso, received the university's Burlington Resources Foundation Teaching Award.

\section{J. Theodore Anagnoson, California} State University, Los Angeles, and Richard DeLeon, San Francisco State University, were awarded $\$ 76,000$ from the National Science Foundation's Faculty Enhancement Program to conduct two workshops of one week's duration each on the techniques of exploratory data analysis during summer, 1994. The workshops are aimed at faculty teaching undergraduate social scientific

Mohammed Ayoob, professor of international relations, James Madison College, Michigan State University, has been awarded the Ford Foundation Fellowship in International Security by the Watson Institute of International Studies, Brown University, for the year 1993-94 to work on a book on "Third World Security in the PostCold War Era."

Carl Boggs of National University has been named the recipient of the first Christian Bay Award for a paper entitled "Social Movements, the War Economy, and the Dilemmethodology courses. mas of Political Strategy" which was presented at the 1992 Annual Meeting.

John Creighton Campbell, University of Michigan, was awarded a Masayoshi Ohira Memorial Prize for his book How Policies Change: The Japanese Government and the Aging Society (Princeton UP, 1992) for 1993.

Jill Crystal, The University of Michigan, was awarded the U.S. Institute Peace Grant in 1992.

Abba Eban, former Israeli Ambassa- dor to Washington, has been appointed to deliver next year's Castle Lecture in Ethics, Politics and Economics at Yale University.

Martha Feldman, University of Michigan, received a Literature, Science, and Arts Excellence in Education Award in 1992.

Malcolm L. Goggin, associate professor of political science at the University of Houston, has been selected for the Fulbright-Hays Higher Education Linkages Program of Faculty Exchanges. He is spending the 1993-94 academic year at the University of Strathclyde in Glasgow, Scotland, while Reader (professor) David Judge, from Strathclyde, visits the University of Houston.

William K. Hall, professor of political science and chairman of the department of political science at Bradley University, was the recipient of the Bradley University Putnam Award for Excellence in Teaching in 1992.

Beverly G. Hawk, University of Alabama-Birmingham, has received the Sigma Delta Chi Award for research in journalism for her edited volume Africa's Media Image. The award is given annually by the Society of Professional Journalists for the best investigative study about some aspect of journalism.

John E. Jackson, University of Michigan, received a Fulbright Scholar Award to study politics in Poland in 1993.

\section{National Conference of Black Political Scientists in the Profession, 1993 Officers}

President-Elect: William Boone, Clark Atlanta University

Treasurer: Sheila Ards, University of Minnesota

Council: $\quad$ Earl Picard, Clark Atlanta University

Maurice C. Woodard, Howard University and American Political Science Association
Sheila Ards 


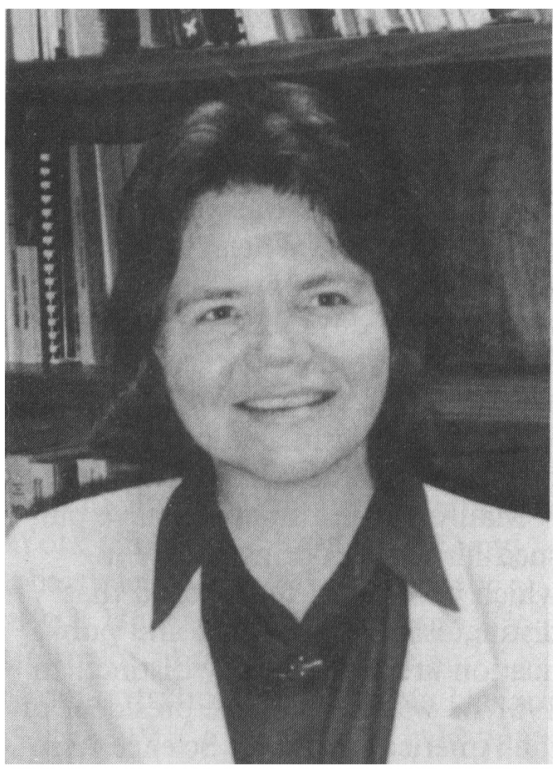

Beverly G. Hawk

Laura S. Jensen, a doctoral candidate in political science at the University of Connecticut, was chosen to receive a $\$ 17,500$ National Endowment for the Humanities Dissertation Award for 1993-94 to support the completion of her dissertation, The Entitlement Mentality: American Expectations of the State. Jensen's research proposal was one of 50 selected nationwide from a pool of 1,475 applications in the inaugural competition of the NEH Dissertation Grants Program, which was funded by Congress to encourage excellence in humanities education and scholarship.

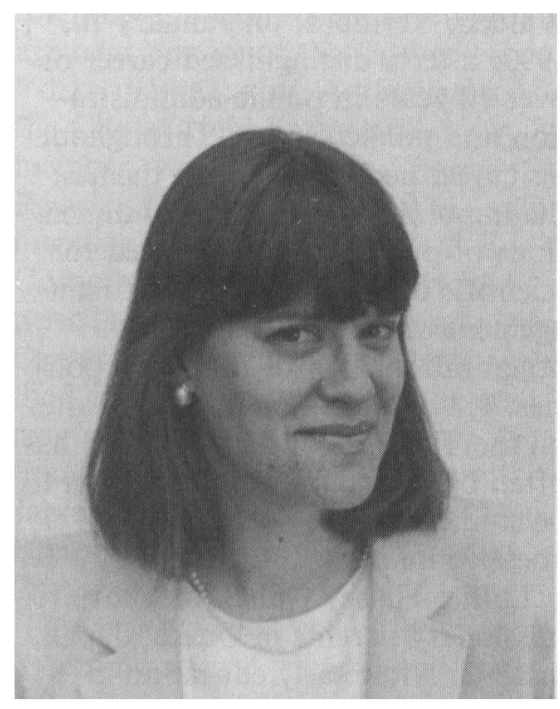

Laura S. Jensen
Nolan E. Jones, director of justice and public safety, National Governors Association, received a citation for Excellence in Emergency Management from the Federal Emergency Management Agency for his efforts in raising the priority of emergency management with the nation's governors.

John W. Kingdon, University of Michigan, received a Literature, Science, and Arts Excellence in Education Award from the University of Michigan in 1992.

Kenneth Lieberthal, University of Michigan, received a Literature, Science, and Arts Excellence in Education Award from the University of Michigan in 1992.

Joseph F. McGowan, a May 1993 Suffolk University graduate, is the winner of the 1993 American Society for Public Administration, Massachusetts Chapter, award for the Outstanding Student of Public Administration.

John J. Mearsheimer, department of political science, University of Chicago, was appointed a Phi Beta Kappa Visiting Scholar.

Kenneth J. Meier, professor of political science, University of WisconsinMilwaukee, and Joseph Stewart Jr., professor of political science, University of Texas-Dallas, have been honored by The Gustavus Myers Center for the Study of Human Rights in the United States for the publication of their book The Politics of Hispanic Education (SUNY Press).

Joshua I. Miller, department of government and law, Lafayette College, was named a National Humanities Center Fellow for the academic year 1993-94 for his study entitled "William James and Democratic Action." He was also recognized as a Jones Faculty Lecturer.

Lawrence Mohr, University of Michigan, was given the 1992 Donald Campbell Award for being an outstanding methodological innovator in public policy studies.

Rosemary O'Leary is the recipient of the 1993 Daniel Patrick Moynihan Award for Outstanding Research, Teaching, and Service by an Untenured Faculty Member at the Max- well School of Citizenship and Public Affairs at Syracuse University.

A. F. K. Organski, University of Michigan, was given APSA's Lifetime Achievement Award in the Study of Conflict in 1992.

Glenn R. Parker, Distinguished Research Professor at Florida State University, has been awarded the John Adams Chair in American Studies (Netherlands) by the Fulbright Scholar Program for the 1993-94 academic year.

Ilan Peleg, Charles A. Dana Professor of Social Sciences and head of the department of government and law, received the $\$ 2,000$ Thomas Roy and Lura Forrest Jones Award for superior teaching and scholarly contribution to his discipline.

Paul A. Rahe, University of Tulsa, was awarded a fellowship by the National Endowment for the Humanities for 1993-94 to work on a book tentatively entitled An Archaeology of Modern Virtue. His book, Republics Ancient and Modern: Classical Republicanism and the American Revolution (Chapel Hill: University of North Carolina Press, 1992), has been chosen as an Alternative Selection by the History Book Club for June, 1993.

Steven Rosenstone, University of Michigan, received a Literature, Science, and Arts Excellence in Education Award from the University of Michigan in 1992.

Giovanni Sartori was named political sciences doctor, honoris causa, at the University of Genova in 1992. He has also been elected a member of the Accademia dei Lincei.

Arlene W. Saxonhouse, University of Michigan, was named as the James Orin Murfin Professor of Political Science at the University of Michigan from September 1993-August 1996.

Kim Lane Scheppele, University of Michigan, has been named the Arthur F. Thurnae Associate Professor of Political Science and Public Policy. Professor Scheppele will also be teaching a course on abortion in comparative constitutional law for a group of lawyers from all over Eastern Europe. Funded by the Ford 
Foundation, the "Raising Rights Consciousness" program is designed to teach lawyers from Eastern Europe and the former Soviet Union about Western legal theory.

Adam Silverman and Caroline Coscia, recent graduates of Suffolk University's Master of Public Administration program, were chosen to be Presidential Management Interns.

Hanes Walton, Jr., University of Michigan, was given the 1993 Alumni Award for Distinguished Postgraduate Achievement in the Field of Education from Howard University.

\section{In Memoriam}

\section{Maure L. Goldschmidt}

Maure L. Goldschmidt, professor emeritus of political science at Reed College, died this past January in Portland. He had suffered from Parkinson's disease for several years.

Maure was a masterful teacher/ scholar, a major figure in the history of Reed College, and a person of great repute among American political scientists. He brought to the teaching of political theory a capacious and tough-minded intellect, an abiding interest in the nutsand-bolts of politics, and a deep devotion to the ideals and ambitions of a democratic polity.

His personal and professional lives were inextricably bound up with the life of Reed College. He graduated from Reed in 1930. He was one of an unusually large number of Reed students who became Rhodes Scholars, and after finishing his work at Oxford returned to Reed in 1935 as an instructor in political science. During the Second World War he worked in the Office of Price Administration and in the anti-trust division of the Department of Justice. In 1944 he earned his Ph.D. from the University of Chicago and, after teaching at Chicago and C.C.N.Y., returned again to Reed in 1946, this time permanently. In 1950 he was named Cornelia Marvin Pierce Professor of American Institu- tions, a position he held until his retirement in 1974. He was subsequently awarded an honorary doctorate from his alma mater.

His career was filled with many of the awards, accomplishments, and distinctions that one expects of a first-rate academic: prestigious fellowships from the Social Science Research Council and the Ford Foundation, visiting professorships at Berkeley and the University of Washington, a Mellon distinguished lectureship at Reed, a Fulbright award in Hong Kong. He was also a research associate of the Hoover Institution at Stanford, and was long an active member of the Oregon chapter of the ACLU. Some of his achievements were perhaps less orthodox. Between 1966 and 1968, for example, he was chair of the department of government at the University of Nairobi in Kenya under the auspices of the Rockefeller Foundation.

But none of this really captures the character of Maure's career or the nature of his contribution. He was an intellectual in a rather oldfashioned sense, an expert in political theory and in the history of political thought (he was especially fond of Rousseau) who could also converse with power and substance in numerous other domains including economics, social theory, and history proper. He brought to all of these concerns an impressive and, in some circumstances, daunting intelligence, and a seemingly tireless capacity for intense and wide-ranging study. $\mathrm{He}$ was not a widely published scholar (though see his fine essay in McCoy and Playford's classic reader, Apolitical Politics). His preferred mode of intellectual activity was the conversation, roughly in Oakeshott's sense; and because of this, and because of his remarkable intellectual talent, he was in many ways and for many years a virtual embodiment of the spirit of Reed College as an institution devoted to serious intellectual endeavor in a context of undergraduate teaching.

Talking with him was inevitably an education. He loved to ask questions, and if his version of the elenchus was occasionally more tolerant than the original, it was always painfully clear that he was really only interested in, and prized above all else, intellectual excellence. When one came to speak with Maure, one came prepared.

He was hard-nosed in his devotion to both political and pedagogical principles; but his was also a most generous nature. When retirement was thrust upon him, as it generally was in those days, his reaction to Reed's new young political theorist was one of warm support and intellectual enthusiasm. He just wanted to talk about political theory with me.

Maure was fortunate to have pursued his career during a time in which it was well understood that distinguished scholarship and publication are conceptually distinct. In 1961 he was elected vice president of the American Political Science Association; in 1965 he became president of the Western Political Science Association. These important honors, which today often reflect a rather new set of values and ideals, were testimony to his standing in the profession as a political scientist of genuine consequence. As such, they acknowledged the potentially great significance of a career devoted largely to undergraduate education, and served to underscore Maure Goldschmidt's status as a scholar/ teacher of the very highest order.

Peter J. Steinberger Reed College

\section{Luther Halsey Gulick}

Luther Halsey Gulick died in Walden, Vermont, on January 10 , 1993, after a distinguished career of over 70 years in public administration and public service. Throughout his career he pursued three themes: the importance of the ethical dimensions of public action, the need for scientific approaches to public management, and the influence of organizational forms on public policies. His most famous work, "Notes on the Theory of Organization," has often been criticized but continues to be studied as an original and provocative intellectual achievement.

Luther Halsey Gulick was born to missionary parents in Osaka, Japan, in 1892. After early education in Japan and Germany, he attended the Hotchkiss School in Connecticut. He 